\title{
Development of an Automated System for the Analysis of Cell-Free Fetal DNA from Maternal Plasma for Non-Invasive Pre-Natal Diagnostics ${ }^{\dagger}$
}

\author{
Josep Lluís Acero ${ }^{1, *}$, Carmen Bermudo ${ }^{1}$, Teresa Mairal ${ }^{1}$, Ciara O'Sullivan ${ }^{1,2}$, Ian Riley ${ }^{3}$ and \\ Ioanis Katakis ${ }^{1}$ \\ 1 Universitat Rovira i Virgili, Av. Països Catalans 26, 43007 Tarragona, Spain; \\ carmen.bermudo@urv.cat (C.B.); teresa.mairal@urv.cat (T.M.); ciara.osullivan@urv.cat (C.O.); \\ ioanis.katakis@urv.cat (I.K.) \\ 2 Institució Catalana de Recerca i Estudis Avançats, Pg. Lluís Companys 23, 08010 Barcelona, Spain \\ 3 Labman Automation Ltd., Seamer Hill, Seamer, Stokesley, North Yorkshire TS9 5NQ, UK; \\ iriley@labman.co.uk \\ * Correspondence: joseplluis.acero@urv.cat \\ † Presented at the 5th International Symposium on Sensor Science (I3S 2017), Barcelona, Spain, \\ 27-29 September 2017.
}

Published: 1 December 2017

The analysis of circulating cell-free (cf) DNA from plasma, serum or urine, has the potential to serve as a non-invasive approach to detect and monitor targets associated with certain diseases. In 1997, the presence of fetal DNA in the plasma and serum of pregnant women was demonstrated [1]. This opened new perspectives in the field of non-invasive pre-natal diagnostics since the analysis of cell-free fetal (cff) DNA can provide information about pregnancy-related disorders (pre-eclampsia, pre-term labour), chromosomal aberrations (aneuploidies) and genetic disorders (cystic fibrosis, thalassaemia, Huntington's disease) [2].

We report on the development of an automated and integrated modular system for the isolation, amplification and detection of cffDNA from maternal plasma for non-invasive pre-natal diagnostics. The system consists of a first module for the cfDNA isolation from plasma based on silica-coated magnetic beads technology. Subsequently, the cfDNA obtained is introduced to a second module which is based on a polymeric microsystem containing a capillary electrophoresis step for the size separation of the fetal DNA from maternal DNA. Finally, the cffDNA is transferred to the amplification/detection module. This module consists of PCB (Printed Circuit Board) electrode arrays functionalized with surface immobilised primers for the multiplexed isothermal recombinase polymerase DNA amplification (RPA) and electrochemical quantitative detection of specific genetic sequences.

Acknowledgements: The research leading to these results has received funding from the People Programme (Marie Curie Actions) of the Seventh Framework Programme of the European Union (FP7/2007-2013) under REA grant agreement no. 600388 (TECNIOspring programme) and from the Agency for Business Competitiveness of the Government of Catalonia, ACCIÓ.

\section{References}

1. Lo, Y.M.; Corbetta, N.; Chamberlain, P.F.; Rai, V.; Sargent, I.L.; Redman, C.W.; Wainscoat, J.S. Presence of fetal DNA in maternal plasma and serum. Lancet 1997, 9076, 485-487.

2. Daley, R.; Hill, M.; Chitty, L.S. Non-invasive prenatal diagnosis: progress and potential. Arch. Dis. Child Fetal Neonatal 2014, 5, 426-430.

(C) 2017 by the authors. Licensee MDPI, Basel, Switzerland. This article is an open access article distributed under the terms and conditions of the Creative Commons Attribution (CC BY) license (http://creativecommons.org/licenses/by/4.0/). 